\begin{abstract}
Evan Mwangi Masculinity and nationalism in
Evan Mwangi was born and brought up in Kenya. Educated at the University of Nairobi and got a Ph.D. in Literature in 2003. He is currently teaching Anglophone African Literature and African Studies at Ohio University, Athens, USA. \section{East African hip-hop music}

\title{
Masculinity and nationalism in East African hip-hop music
}

East African music aligns itself with nationalistic desires while attempting to create a transnational and regional agenda that goes beyond individual nation-states. Hip-hop music appears at pains to define itself as different from the western art-forms with which it is hastily associated by instantiating localized forms and creating a different locution. This paper surveys East African hip-hop to demonstrate that the music is a productive site upon which the local, the national, and the global contest and negotiate. We demonstrate that central to the music's identity politics is the notion of masculinity, in which the construction of community is interpreted as a masculine enterprise. The audiences also invest the music with political and nationalist meanings that are fraught with sexualized readings. On the whole, the music rejects hostile nationalism but male artists tend to represent women negatively in their grand national, regional, and pan-African projects. Indirectly indicating the depth of the hegemonic masculinism they operate under, women artistes express a desire to deconstruct male constructs. At the same time they suggest that, in spite of themselves, their critique has to be cautious and subtle. Key words: Masculinity, Nationalism, hip-hop music, East Africa.

Styling itself as the "Historians", a Kenyan underground hip-hop group stakes out an identity as part of Nairobi in terms of its prowess in three important areas of its country's life: kuwaka, kupa'lie, and kuhanya (drinking, partying, and $\mathrm{f}$ - .) The song, "Hepi" (Good Time), may be a jocular artistic item by youngish and little known city armatures whose main aim is just to invoke their neighbourhoods without saying anything serious about the places mentioned, but the idea of masculinity the song expresses as the defining quality of their identity is replicated in the other songs. Indeed, the word "hanya" and its variants recur as the crux of the young people's identity formation in the emergent Kenyan hip-hop rhymes. Similar sexual activity is insinuated with various degrees of subtlety in hip-hop songs from the other East African nations. In the songs, the discursive reference point becomes the phallus, making the music of the nation a masculinist project that relies on an arbitrary and evolving idea of the masculine as seen against a resisting and problematic notion of a culturally interpreted femininity.

This essay calls on male and female hip-hop artists from Kenya, Uganda, and Tanzania to explore the presentation of nationalist and 
gender politics in the region's popular culture. Our aim is to analyse the way the region's hip-hop expression employs masculinity as a trope in grounding an elusive East African identity. Our argument is that hip-hop music has been deployed to enhance a sense of nationalism and transnational and regional desires against the narrow-minded ethnocentric identifications that threaten the oneness of the ethnically variegated nations. We demonstrate that because of its sexualised presentation of the nation and the region, the music is haunted by notions of hegemonic masculinity. We show that contrary to previous studies that see women as passive in popular cultural productions, female artists undermine the stereotypes and tease out of male characters and audiences a different kind of masculinity. We proceed from the observation of nationalism as typically a product of masculinized memory, masculine humiliation and the hope for the restoration of the masculine (Enloe, 1990: 45; Nagel, 1998: 244). In the narratives of the nation women are icons to be won by the male while they remain in the matrix of marginalization in vital decision-making. In nationalism, the "real actors are men who are defending their freedom, their honour, their homeland and their women" (Nagel, 1998: 244). In the music under analysis, the male remembers betrayal by a woman who behaves outside the expectations of the nation and who undermines the man's masculinity. Women are to be controlled for the masculinity to be affirmed and restored. Women artists attempt to reverse the portrayal through cautiously disruptive questioning of hegemonic masculinity.

It is because he understood the dynamic essence of culture that Taban lo Liyong insisted in Popular Culture of East Africa that the region's traditional oral expression has to contend with modern forms and ideas. East African popular culture has appropriated contemporary art to serve its traditional functions more meaningfully in an intensely globalized world. Associated with American urban expression, hip-hop is a genre of African music in which rhyming lyrics are chanted to a musical accompaniment. It is popular with the youths without much knowledge of traditional culture but, as in traditional oral literature live performance, the effects of hip-hop vary with the performer, the audience and the occasion. The costumes worn in the performance are invoked in the songs and include bling bling (chains), sagging baggy trousers, rings, pendants, and sports shoes. These costumes are trendy and expensive by East African standards where the majority live below the poverty line and the youths are largely unemployed. The music has therefore had to change and adapt to a new environment. The cos- 
tumes do not necessarily have to be expensive and can be bought in open-air second-hand markets. The music is also played in different public places like public transport vehicles and on the radio; the audience do not necessarily need to dress us in the hip-hop version.

It is in hip-hop that the youth most intensely appropriate western culture while at the same time resisting its hegemony to forge a new form of nationalism. Thus, it is important to not only heed Paul Gilroy disapproval of the nationalist blinkers with which American theorists study the genre in a way that occludes its Caribbean antecedents but also to pay attention to the new destinations the music goes to as it returns to Africa. The study of other hip-hops would decentre the predominant nationalism. Hip-hop is particularly important in giving us insights into East African identities because it is performed by young people grappling with their sense of self. Still unofficial in a culture that would express itself in a language which appears to be unserious, the underground music offers a more genuine expression of what the young people would like to be. The music is also East African. Although its origins can be traced to New York's West Bronx area, thanks to Jamaican DJ Kool Herc's fusion of Caribbean articulations into western rhythms, the East African hip-hop is a localized mode of expression that expresses international impulse without distorting the local. Herc's rap had its origins in African verbal and rhythm game. But when hip-hop culture returns to Africa, it is largely seen as foreign because of its association with American urbanity; the artists have had to go out of their way to pledge their allegiance to the nation and its political and moral desires. Western hip-hop music started filtering back into Africa in the 1980 s as a result of intense globalisation and liberalization of the economies. But it is in the 1990s that the music gained roots in East Africa.

Developments in the individual nations and the globe have been responsible for the growth of hip-hop culture. With the liberalization of the airwaves in East Africa and the attendant growth of FM radio stations and independent TV stations in the final quarter of the 1990s, popular music became more than ever before a formidable genre in the region's cultural production. By the end of the decade, Kenya alone, whose airwaves had been dominated by the government-owned Kenya Broadcasting Corporation, had in place a total of nine private television stations and 19 radio broadcasters being accessed in various parts of the country. These were in addition to $43 \mathrm{VHF} / \mathrm{UHF}$ television stations, $17 \mathrm{FM}$ stations and 22 medium wave receivers. Tanzania broke the state monopoly on broadcasting and had eight new FM radio stations 
and five television stations. Uganda, too, privatised state-owned radio and TV and licensed other private broadcasters. The liberalization was half-hearted and a far cry from what was expected because the stations, although privately owned and ran, functioned under the gaze of the state. While some of the stations had political news programs, the majority of them specialized in the more politically innocuous entertainment options, unofficially for fear of revocation of licences. Therefore, music became the staple of media programming since the 1990s, but the evasion of politics did not mean erasure of discussion of public affairs because the music itself was political, albeit in an indirect way. Music offered a new paradigm navigating politics, especially among the East Africans between ages 18 and 30, who are the demographically dominant group. Particularly critical were new genres such as hip-hop art, which dominated top-ten lists since the late 1990s.

So intricate is the bond between hip-hop music and nationalism that even in a fluid field like the internet, the music is accompanied by visual signifiers of the nations where that music comes from as evinced by Francis Banyikwa's web-page of East African hip-hop hits, in which the music plays against the visual background of the flutters of national flags of the East African nation the particular song comes from. The national differentiation indicates that the music is not uniform. Kenya followed a liberalized capitalist-based economy and has therefore been exposed to western music more intensely than Tanzania which followed a socialist ideology of self-realisation. During the heyday of Tanzanian socialism, which ended in the 1990s, the artists were required to help in the nationalist project of disseminating government policies. For its part, Uganda suffered political instability from 1968 to 1986 and is still struggling to rebuild its institutions. Therefore, while some Kenyan musicians can be irreverent and get away with it, Tanzanian and Ugandan hip-hoppers are more restrained even when deconstructing political and artistic conventions. This is not to say all Kenyan hip-hoppers are trivial. There is music addressing such issues as corruption, the Aids scourge and institutionalized hypocrisy in the hip-hop music from the three countries.

The music seems to be more interested in the destinies of the nations than in where it originated from. The notion of nations as fictional constructs proposed by various theorists is apt in making sense of the fictions of masculinity conjured into existence by artists in their discourse of nationalism. If Ernest Gellner sees nationalism as capable of constructing nations "where they do not exists" (1964: 165), we see the 
nation as over-determined by many forces among which popular culture inserts itself to consolidate and to contest the nation. Popular culture not only performs the nation into existence, it also exploits the popular notion of the nation to create its own popularity. In the introductory chapter of his Nation and Narration, Homi Bhabha suggests that nations and fictional narrations are an articulation of each other, a fact that Edward Said endorses in Culture and Imperialism when he says "nations are themselves narrations" (1993: xiii; emphasis his). Benedict Anderson argues in Imagined Communities that the novel and other forms of mass communication help forge variegated elements of a community into a homogenous nation. According to Anderson (1991: 8892), the particular systems of communication characterizing societies with popular literacy allow the imagined population of the imagined community to be extended far beyond the bounds of the knowable or face-to-face community of societies characterized by oral communications. Key to Anderson's formulation is the emergence of the printing press. But in a society such as East Africa where cultural production is still oral, and literacy rates are below 40 percent, the imagination of the nation is more through the oral discourse rather than the printed materials. It is especially in music that the nation is inscribed into existence and its boundaries sometimes dissolved by the musicians' trans-national impulses.

Various studies have noted the use of music for nationalistic purposes in East Africa. Kelly M. Askew's Performing the Nation has articulately shown how the Swahili taarab music has been employed by the Tanzanian society to forge a national cultural politics. With reference to Tanzanian music, Rugatiri D. K. Mekacha notes the nationalistic impulses behind the "jazz bands" and "orchestras" during the first decades of Tanzanian independence since 1962. The declared aims of these groups, which would at times be stated in their constitutions was "to educate the masses, and to promote the presentation of social norms relevant to the Tanzanian culture (...) and to promote the national ideology of socialism and self-reliance" (1992: 99). Makecha and Beck separately have seen that the music, in pursuit of moralistic and nationalistic projects, stereotype Tanzanian women. Beck concedes that looking at only a limited scope of music might give a wrong picture of the East African diverse gender and political agendas. Emerging at a time of intense liberalization, hip-hop and rap, which are sometimes irreverent, are deployed by the artists to express new perspectives. More heavily coded, they demand to be read as layered texts that could be carry- 
ing messages other than the ones openly stated. Women hip-hop and rap musicians have also been a little more open in their dismantling of masculinist ideologies. Fusing different languages, voices and genres, the music helps the society negotiate new identities.

East African hip-hop does not have a mainstream language because there is no single language that can be spoken by the whole population. Luganda and Kikuyu are widely spoken in the central regions of Uganda and Kenya respectively. There is hip-hop music in Luganda by groups such as Able 4 but Kikuyu rap is a parody of old songs in the language. Swahili is spoken in Tanzania but in Kenya and Uganda it is the language of the army, police and other authoritarian forces. In the three countries, English is spoken by the educated elites. To overcome the barrier, the musicians reject Chinua Achebe's call in "The English Writer and the English Language" in Morning Yet on Creation Day to the African artists to use an African variety of English and Ngugi wa Thiong'o exhortation in Decolonising the Mind that artists use indigenous languages. Instead, hip-hop artists mix different languages, liberating the music from the monolingualism of earlier forms to express tolerance and desire for diversity. Tanzanian music is almost fully in Swahili but it also uses snippets of local languages and English. Kenya's varieties of hip-hop are linguistically adventurous in their use of different languages. For example, Klear Kut, Uganda's foremost hiphop group, combine smooth hip-hop with rapping in French and Swahili. The introduction of indigenous languages in the Ugandan curriculum could also account for the more use of local languages in Ugandan music than in the other countries. Beyond artistic novelty, some artists are not competent in any single indigenous or foreign language. Born in the city and removed from the village, they cannot speak rural languages and yet they are not educated enough to be proficient in English as an artistic medium. Those who have a mastery of single languages are aware of the status of their audiences who would prefer the mix of tongues. In fact, there are moments the artists seem to be going out of their way to speak any single language badly.

Swahili and English are spoken in the three East African nations, and the musicians exploit the languages to spread their music beyond the boundaries. Therefore, the nation imagined by the music does not always conform to the established cartography. Tanzanian musicians Mr Nice (Lucas Mkenda) and Darda King variously try to forge what Anderson (1983: 7) calls a "deep horizontal comradeship" that goes beyond the political boundaries of the nation states. They imagine East 
African nations as a single community. This is not through haranguing us into conformity with a nationalist ideology but through the invocation of places that traverse the boundaries of the three East African nations. At the same time, they boost sales of their music by making a wider audience identify with the production. A Tanzanian, Darda King invokes in his "Waswahili" the other nations of East Africa to create a new nation that goes beyond the official boundaries:

Wakenya, Wauganda

Sisi zote waswahili

Na hata Wasomali wanajua Kiswahili

(Kenyans, Ugandan

We all speak Swahili

And even the Somali know Swahili.)

Swahili is not as popular in Somali as it is in Kenya and Tanzania but by drawing our attention to the phonetic affiliation between the words "Somali" and "Swahili", Darda King signifies the possibilities of including Somali in the trans-border nation of rap. To fully forge this transnational community and concretise its future, Darda King laughs at deviant sexuality that compromises the idea of the male. For their part, Tanzanians Soggy Doggy and Mr Nice have each a song called "Fagilia" (sweep) which true to their title swept the East African crowds off their feet between 2002 and 2003. Figuratively, to "fagilia" is to praise, acclaim and cheer on somebody for good deeds. In his song, Soggy Doggy is cheered for his masculine efficacy to turn the pool-table rules on their head. He chidingly informs us that girls ("kina Anifa") will "fagilia" him anyway, even if we don't like his subversive acts. Mr Nice's "Fagilia" attempts to forge the Tanzanian mainland and the Zanzibar and Pemba islands into one nation and the rich and the poor into one community by creating possibilities of love between sexual and class opposites. What is remarkable is that the two songs self-consciously invoke the capital cities of the three East African nations of East Africa - Tanzania's Dar es Salaam, Uganda's Kampala and Kenya's Nairobi to imagine a regional community and perhaps to seek acclaim in spaces beyond the nation state. Uganda's Lyrical G has been a sensation since he joined the rap act in 1994. But like "Fagilia" by Mr Nice, it is his song, "East African Party", that swept East Africa off its feet, remaining at the top of the radio charts for weeks on end. Composed for the radio, the song invokes the cities of Kenya, Tanzania and Kampala as it creates the impression of cross-border celebration. The "party" in the song cli- 
maxes with questions regarding which girl the East African countries the persona should sleep with.

Tim Edensor (2002: 12) argues that traditional cultural forms and practices of the nation are supplemented, and increasingly replaced in their effective power, by meanings, images and activities drawn from popular culture. Aware of possible rejection as acts of rebellion, East African artists assume respect for old forms while deconstructing them. In his "Manzi wa Nairobi" (The Nairobi Girl) Kenya's Nonini (Herbert Nakitare) urges the city girl to ululate as in a traditional celebration. Although his music tends towards the obscene, it acknowledges the traditional culture to create an aura of respectability. In his version of hip-hop, Tanzania's Mr Nice inserts local expressions and nursery rhymes in a tradition of distinctly Tanzanian hip-hop. So independent and localized is this mode of expression that it has been christened Bongo Flava (for Bongo, the slang name for Dar es Salaam and "bongo", the Swahili word for "mental faculties" needed to survive in Dar es Salaam and decode the lyrics). Uganda's Joseph "Chameleone" Mayanja is not only chameleonic in the multiple colours of the consumes he wears in live performance, but also in the way he unpredictably fuses styles from western and African acts to forge a contemporary style that is Ugandan. Other musicians deploy proverbs and other traditional devices to identify with their communities. There are musicians who rework old melodies, transforming them into the more popular hiphop tunes. More fundamental is the invocation of established musicians as rap unwraps itself to its audiences. A case in point is Tanzanian Darda King who alludes to the music of Tabora Jazz Band and other music of "kale" [of the past]. While hip-hop is usually seen in terms of protest and resistance, Ugandan music attempts to enhance traditional moral values using modern instruments and fusion of voice. "Enguuli" by Damascus $\mathrm{ft}$. James is an excellent example of hip-hop melodies that speak against harmful behaviour. Unlike Kenya's Historians to whom it is positive to waka (imbibe), Damascus condemns Enguuli, an illicit brew, not only because of the way it makes men and women to sexually misbehave but also because, contrary to the popular misconception, Enguli does not turn you into "vumbi" [dust/wildly potent]:

Omukisa omubi gwa nguuli, buli mukazi gw'owerekera y'atadda.

Omukazi afuukafuuka kingiringiri, bw'ayoza empale za bba ezo tazaanika. (...)

Baali batulimba, nti abaguuli babeera ba vumbi.

(Enguli is of bad news! Every lady you escort does not return 
For a woman, she becomes a nuisance and cheats on her husband

(...)

They were lying to us when they said; that enguli makes you more potent.)

For the sake of national development and in defence of one's masculine virility, one should not take Enguli. By using local expression and traditional idiom to criticize a traditional brew, the artist underlines the need for the transformation of ethnic traditions to conform to the desires of the nation.

It is in the language of hip-hop music that the identity politics is launched and played out in the most profound way. The musicians mix local languages with English and Kiswahili to articulate in a hybrid locution that defies confinement to any traditional linguistic community. The Sheng language (a combination of Kiswahili and English and other local languages) has crept more profoundly in pop cultural production, with many groups of musicians expressing themselves in the slang. What is intriguing is that while these musicians are seen to be alienated from their rural roots and languages, they see themselves as defining themselves from other global artists and imported music. An example of such an artist is E-Sir whose death in March 2003 in a road accident at the age of 21 caused national sadness, especially among the young who had identified with his music. The name E-Sir for the Muslim musician points to his appropriation of English; for it is an Anglicised version of his real name Issa. At the same time, it suggests globalisation as the hyphenated ' $\mathrm{e}$ ' suggests the grammar of electronic web communication. E-Sir was among the pioneering young musicians behind the emergence popular Kenyan hip-hop. The beats in English, Swahili, Kenyan languages, and Sheng were seen by his fans as disproving the myth that Kenyan music could never compete with imported pop. He uses Sheng to connect intertextually with songs done in local languages and therefore forge a sense of the nation. His music, too, is masculine in that he presents himself as the toast of women or as a police inspector of desire who has come kuwashika [to arrest] women. Kushika (arrest/hold) is the Bantu euphemism for the act of a man forcibly having sex with a woman. Therefore, when Inspector E-Sir comes to shika madada (arrest girls) he intends to generate connotatively sexual interpretation.

Micheal Kimmel (1996: 2) defines gender as "a set of cultural meanings and prescriptions that one culture attaches to one's biological sex". 
East African men and women have over the years been expected to behave in a certain way, and any deviation from the standards would incur the person censure from the arts if not a penalty from the state. The behaviour is tied to one's biological characteristics that are invested with cultural meanings that cannot be easily disrupted. East African societies do not discuss homosexuality openly because it is a taboo topic and the sexual orientation is illegal. The illegality of the orientation has not only been reinforced by state legislation but through statements by respected nationalists. The first and the second presidents of Kenya Jomo Kenyatta and Daniel arap Moi have been categorical that same-sex relationships are unnatural and un-African in their Facing Mount Kenya (1938), Kenya African Nationalism: Nyayo Philosophy and Principles (1986) respectively. Uganda's Yoweri Museveni has been vocal against homosexuals in his country and Tanzania's successive presidents (Julius Nyerere, Ali Hassan Mwinyi and Benjamin Mkapa) have expressed anxiety over the practice. The anxiety with which nationalists respond to the practice indicates that it takes place and could be a threat to the masculine figuring of the nation.

Like the statesmen, hip-hop music is nationalist in this sense, echoing the expectations of the nation. "Hip-hop artists don't have money to pay for studio time to make a track about homosexuality when there is stuff like Aids and the war in the north," says a Ugandan fan and supporter of the genre. This means that homosexuality is not a serious issue, and that the artists prefer to talk about more important topics such as the war between the Ugandan government and the Lords Resistance Army rebels in the northern part of the country. When the music chooses to mention homosexuality, it is presented as a pathology. Such a treatment wins the songs instant popularity, and more so when the song is by a popular artist like Tanzanian musician Lady Jay Dee (Judith Wambura). An internationally respected artist since she was awarded Best Female Artist 2001 in the M-Net's "Where U At" awards, Lady Jay Dee has set new standards in African music video. In her "Wanaume Kama Mabinti" (Men like Women), she excoriates hypocrisy and meanness of the urban male who seems to behave outside the traditional gender norms.

Mnakula kunywa na kuvaa, siku zinaendaa

Vya bure hupenda kupewa, wala hamna fikira

Kila upande mnafiti. siku zinaenda

Vinywa vimejaa ufitini, wanaume kama mabinti

(You eat, drink and dress expensively, time is moving 
Free things you like, and you're thoughtless

All sides, hypocrite, time is moving

Mouths full of ill-will, men like women.)

The song is quick to qualify that the target of its satire is not all men but those who have failed the traditional male roles. It insists the need for self-reliance as the ideal of masculinity and catalogues the undesirable aspects of the dependent man. The man comes through as an inveterate liar, a braggart and a mean and garrulous individual. The artist is not directly talking about homosexuality, but the orientation becomes a veiled metaphor with which to construct men who gossip and are reliant on other people. This is in a line that is ambivalent in its use of the Swahili word "shoga" which would mean "homosexual" and "my intimate friends":

Shoga zangu hebu leteni magauni tuwavishe

Hijabu tuwafunge na vimini vitopu tuwaazime

(My friends, let's clothe them in flowing dresses

[or Please, let's clothe these our gays with flowing dresses]

Let them wear veils, let's loan them our mini-skirts and tops to wear.)

Whatever the interpretation of the line "Shoga zangu hebu leteni magauni tuwavishe" the male are seen as behaving in a way that does not conform to the normative masculinity. It is because of their negative attributes that the men are sarcastically compared to women. The sarcasm is sharper against their supposedly pathological behaviour of women if they are compared with what the song views as an equally pathological sexuality.

Equally threatening is the city woman who is no longer submissive. So exasperated are some of the songs with the city woman that some musicians declare that they no longer need women. This is an expression of the anxiety of the nation that is confronted by the castrating gaze of an empowered woman. Juma Nature's "Sitaki Demu" (I don't need a Demu) highlights the hybrid status of East African hip-hop. "Demu" is the slang Kiswahili for girl (dame) but in the context it suggests that "demu" is a loose girl, modern and different from the traditional mchuba (betrothed). While using the urban hybridity, the song is ironically critical of the liberties that women have in that interstitial space between traditional Africa and the modernized west. The woman ("demu") is presented as too old for the persona and perhaps more sexually experienced, and therefore a threat to the persona's masculinity and control. She scandalizes him by telling lies that he is a drunkard and a drug 
addict and by laughing at him. She is known all over the city, perhaps because she respects no boundaries in her trade of seduction. Although the city is a site of hunger, the "demu" is loose and money-minded:

Hata kama ni njaa, mama hii yako imezidi.

Niache niwe free nimpate yule nimtakae.

Ambaye najua nitatumia muda wangu kumsaka,

Mtoto aliye wa kweli

Kimwana mwenye uwezo wa kuishi

Kwenye mshelisheli

(Even if it's because of hunger

Set me free to look for the one I want

The one I know I'll spend time looking for

A true child

A girl who can endure

A life of poverty.)

In the song, the city woman is presented as expensive, a motif recurrent in the music of Uganda's Chameleon whose "Bei Kali" (Expensive) while evoking a Pan-Africanism where "yote" (all) from Africa are given "pasi" (permit) to join in the dance the song at the expense of the city Bei-Kali woman who won't sleep in a cheap hotel, won't eat the staple food and won't dance to African music. The speaker in Juma Nature's "Sitaki Demu" threatens to sue "demu" for stalking him. Addressed directly in the second person throughout the song, "demu" is figured as following the persona all over the place even when he unpredictably changes directions. It is in the refrain where we see a connection between the nation and sexuality. In the regularly repeated lines, he emphasizes the speaker regrets that he rejected the advice of the people to avoid the loose woman:

Walimwengu walikwishaniambia

kuwa demu wangu mimi hafai, fai,

mimi nikawabishia nikawaona

Waokuwa ndio hawafai fai.

Hivi sasa mi najuta sitaki demu sihitaji demu

bora nitafute mchumba sitaki demu

Sihitaji demu

(The community had told me

That my demu isn't fit, fit

I paid no attention

I told them it was theirs 
That weren't fit.

Now I regret I don't want a demu I don't need a demu

Better I look for a betrothed, I don't need a demu

I don't need a demu.)

The virgin/whore dichotomy is established at the beginning of the song and maintained throughout. "Demu" is a whore, different from the pure "mchumba". Despite the insults that the persona hurls at "demu" she is desperate and keeps on following him. Not even threats of violence stops "demu" from following the speaker. That the warning against "demu" comes from the community shows that if the city is a possible space for women's liberation, their aggressiveness is presented as a perversity that threatens the stability of the society.

When Ngugi wa Thiong'o said in Writers in Politics that all artists are political, he meant that writing will express the power relations in the society even if the writer is not aware of the politics of the portrayal. I would add that as members of the society and participants in the power struggles, readers also inject their own political beliefs in the interpretation of texts. All readers are readers in politics. To be sure, nationalism and masculinity do not necessarily reside in the wording of the song but in the performance and the audiences' interpretations. Kenya's Gidigidi Maji Maji may have little to do with the nationalist 1905-1907 Maji Maji rebellion against the German colonists in Tanzania but the audiences and nationalists appropriate the group's popular hits to inscribe a new nationalist rebellion against dictatorship and to reinforce their invincibility. Although playing on one of the duo's names, the nomenclature "Gidi Gidi Maji Maji" suggests a kind of badly made porridge that is thin and watery (maji maji) and with solid lumps (gidi gidi). In Dholuo, GidiGidi would suggest "gido" (one who makes people laugh). To be sure GidiGidi and MajiMaji tickle their audiences while at the same time inviting them to construct serious political messages out of the highly playful and parodic songs that while using Dholuo as their main language employ elements of English in their melodies and rapping. Founded in 1999 by Julius Owino (MajiMaji) and Joseph Ogidi Oyoo (GidiGidi) the group is best known for its track Unbwogable, although ever since they recorded Ting Badi Mallo they became an instant hit in East African discotheques. The rendition of the popular Unbwogable (Invincible) in nightclubs excites a multiplicity of interpretations, especially among non-Dholuo speakers. In Dholuo language, the word bwoga means "overpower". GidiGidi MajiMaji have 
Anglicised it by adding the prefix un- and the suffix-able to mean that which cannot be overpowered. Among male revellers, brogga is deliberately interpreted in a playful context to mean coital penetration. When singing along with the artistes, the merry-makers replace some of the parallel expressions for unbwogable with their mother tongue expressions for that which cannot be penetrated in coital exercise. The nationalist appropriation of popular culture that is not in itself nationalistic is seen in the way the Kenya's opposition National Alliance of Rainbow Coalition picked up the song "Unbwogable" to express its mantra of invincibility in the 2002 presidential and parliamentary elections. When the party took power it continued to describe itself as "unbwogable" and the media picked the expression up, with even the BBC employing the term in its broadcasts: "The term became part of everyday discourse with phrases like 'bwoggingly unbwogable' recurring in public discussion. By February [2003], the 'U' word, as it became known, was being used in Parliament" (Hofmeyr, Nyairo and Ogude, 2003: 373). Although originally the song invoked names of opposition politicians, the leaders were mainly from one ethnic group and it is in a later remix that the song was to cover the whole nation with light-hearted portrayal of the destruction of the economy by Daniel Moi's regime (1978-2002).

Women are not necessarily passive in the way they figure themselves. They are highly critical of the male who exploit their stature in the nation to tell lies. We hear this in Kenyan Wahu Kagwe's "Liar". But more profound in its deconstruction of the male while maintaining the notion of nationalism and community is Jayday's other popular song "Siwema". The Tanzanian musician uses the mode of symbolic naming associated with traditional oral poetry in calling the character she talks about and addresses directly in the narrative Siwema (It isn't fair/It's bad). Siwema is male and the name that expresses his behaviour typifies him as a class of East African men - not, strictly speaking, a single person with an inner individuality. Underlined in the choice of name are Siwema's unfairness and his symbolic significance as a type of men. This unfairness is sexualised and gendered because Siwema exploits the persona's devotion to him to construct a sense of masculinity among his friends. His sense of self-importance is deconstructed as a delusion on Siwema's part; the speaker has discovered that Siwema is not a good lover, and that is a victim of Siwema's "mambo ya ajabu" (strange things). He has been bragging among his friend about how indispensable he is:

Unajitapa mbele ya rafiki zako

Kwamba mimi sina lakusema mbele yako 
Umeniweka kwenye kiganja

Unalotaka ndilo ninalofanya

Sababu wewe mzuri sana

Siwezi kupata mwingine kama wewe

Siwema Kaka, unajindanganyaaaaaaa.

(You brag among your friends

That I have no say before you

You have put me in the palm of your hand

I do whatever you bid me to

Because you are so good

I can't get another [lover]

Siwema, my brother, you delude yourself.)

It is because patriarchal masculinity is arbitrary and assumptive that it has to be constantly performed to retain its hegemonic hold on both men and women. Siwema deludes himself through fictional performances of his maleness. The last syllable in the word "danganya" (delude) as used in the above quotation from the song is extraordinarily extended to underline Siwema's self-delusion and sharpen the speaker's disdain for Siwema. It is imperative to note that the delusion is reversed so that it is not the woman who is not deluded that Siwema is a good guy, but it is he who is deluded that he is indispensable. He comes through as ungrateful, but the speaker criticises herself for becoming an easy prey for Siwema.

Siwema's masculinity is pathological because it is not nationalist. This is suggested through the song's use of the journey trope in East African music in which the speaker moves around the country in search of the ideal. The speaker has visited the different parts of Tanzania and found many better young men:

Nimezunguka Tanzania Bara

Unguja na Pemba kote nimefika

Nimewaona vijana wenye sifa

Wenye kujipamba wakapambika

(I've travelled around Tanzania mainland

Zanzibar and Pemba I've gone, too

And seen young men of good morals

And who are spick and span.)

Thus individual males like Siwema who abuse the privileges of masculinity can always be disposed of and the nation will forge ahead. It is 
suggested that there are other competing masculinities that are less hegemonic which the society will use when it disposes of Siwema's brand of masculinity.

To conclude: While largely seen as foreign, subversive, and underground, the East African hip-hop music conflates ideas of masculinity with the notion of the nation. The audiences are not passive. They invest popular hip-hop songs with political and nationalist meanings that are also sexualised. Despite rivalries between groups, the music signals a desire for a trans-border nation and regional integration. Male artists tend to present women negatively but women artists cautiously deconstruct male constructions. On the whole, while the nationalism of East African hip-hop production is not chauvinistic, the music's masculinism is so hegemonic that it is heard in women musicians' art.

\section{Acknowledgment}

I'd like to say a big ahsante (thank you) to Joel Isabirye of the Centre for African Music, Kampala, Uganda, for his insights and assistance.

\section{Bibliography}

Achebe, Chinua. 1975. Morning Yet on Creation Day. London: Heinemann.

Anderson, Benedict. 1991[1983]. Imagined Communities. London: Verso.

Askew, Kelly Michelle. 2002. Performing the Nation: Swahili Music and Cultural Politics in Tanzania. Chicago: University of Chicago Press.

Banyikwa, Francis. 2004. Bongo Explosion. Ontline. http://web.syr.edu/ fbanyikw/BongoMusic.htm) Accessed: 15 May.

Beck, Rose-Marie. 1992. "Women are Devils! A Formal and Stylistic Analysis of Tanzanian Popular Music." In Werner Graebner (ed.). Sokomoko: Popular Culture in East Africa. Amsterdam: Atlanta, GA: Rodopi, 99-114.

Bhabha, Homi. 1990. "Introduction: Narrating the Nation."In Bhabha, Homi (ed.) Nation and Narration. New York: Routledge \& Kegan Paul, 1-7.

Edensor, Tim. 2002. National Identity, Popular Culture and Everyday Life. Oxford: Berg.

Enloe, Cynthia. 1990. Bananas, Beaches, and Bases: Making Feminist Sense of International Politics. Berkeley: University of California Press.

Gellner, Ernest. 1964. Thought and Change. London: Weidenfield \& Nicolson.

Gilroy, Paul. 1993. The Black Atlantic: Modernity and Double-Consciousness. Cambrige: Harvard University Press.

Graebner, Werner. Ed. 1992. Sokomoko: Popular Culture in East Africa. Amsterdam, Atlanta, GA: Rodopi.

Hofmeyr, Isabel, Joyce Nyairo \& James Ogude. 2003. "'Who Can Bwogo Me': Popular Culture in Kenya." Social Identities. 9(3): 373-82.

Kenyatta, Jomo. 1977 [1933]. Facing Mount Kenya. Nairobi: East African Educational Publishers.

Liyong, Taban lo. 1972. Popular Culture of East Africa: Oral Literature. Nairobi: Longman Kenya.

Mekacha, Rugatiri D.K. 1992. "Are Women Devils? The Portrayal of Women in Mwanameka." In Werner Graebner (ed.). Sokomoko: Popular Culture in East Africa. Amsterdam, Atlanta, GA : Rodopi, 115-132.

Moi, Daniel arap. 1986. Kenya African Nationalism: Nyayo Philosophy and Principles. London: Macmillan.

Nagel, Joane. 1998. "Masculinity and Nationalism: Gender and Sexuality in the Making of Nations." Ethnic and Racial Studies. 21(2): 242-269.

Ngugi wa Thiong'o. 1986. Decolonising the Mind. Nairobi: East African Educational Publishers.

Said, Edward William. 1993. Culture and Imperialism. London: Vintage. 